\title{
Sosiaalityön koulutusintressit ja elinikäisen oppimisen periaate
}

\author{
Marjo Vuorikoski
}

\author{
Voidaan sanoa, että suomalaisen hyvinvointi- \\ yhteiskunnan muotoutumisen yksi indikaattori on ollut \\ sosiaalityön professionaalistuminen ja sosiaalityön- \\ tekijöiden koulutuksen kehitys. Artikkelissa kuvaillaan \\ kehitystä noin 50 vuoden saatossa, miten ja milloin \\ jatko- ja täydennyskoulutus tulivat mukaan ja miten \\ elinikäiset oppimismahdollisuudet näkyvät nykyään \\ alan koulutuksessa. Profession tunnusmerkkeihin \\ kuuluvat ammatin tieteellinen perusta ja tiukasti \\ säädellyt kelpoisuusehdot, kirjoittaja muistuttaa.
}

Elinikäisen oppimisen periaate tuli yleiseen koulutuskeskusteluun 1970-luvulla. Tuolloin oli kylläkin tavallisempaa käyttää käsitettä jatkuva koulutus. 1980-luvulta lähtien elinikäinen oppiminen on ollut jonkinlainen iskusana, jota on käytetty mitä erilaisimmissa yhteyksissä. Jo itse termi näyttää sisältävän myönteisen lupauksen jatkuvasta, iäti eteenpäin kulkevasta kehityksestä - ja sitähän länsimaisessa kulttuurissa ihannoidaan yli kaiken. Tosin jotkut ovat epäilleet, onko se jatkuva opiskelu sittenkään niin auvoisaa, sillä monille on tuottanut tuskaa jo pelkkä peruskoulun läpi-istuminen.

Vaikeuksia on usein tuottanut se, mitä elinikäisen oppimisen periaatteella oikein tarkoitetaan.
Elinikäisen oppimisen periaate tuntuu olevan kuin saippuapala, joka lipsuu käsistä jatkuvasti. Siihen sisältyy lukemattomia näkökulmia ja tarkastelutasoja. Ei siis ihme, että se on monine merkityksineen loistava käsite koulutuspoliittisessa keskustelussa, jossa koulutuksen edistysuskoa pyritään ylläpitämään.

Valtakunnan tasolla tämä ihmettely johti 1980luvun lopulla mm. siihen, että Suomen Akatemia käynnisti tutkimusohjelman, jossa yritettiin saada paremmin otetta siitä, mitä tuo lupauksia antava käsite oikeastaan pitää sisällään ja mitä periaatteen toteuttaminen voisi merkitä koulutuksen ja oppimismahdollisuuksien kehittämisessä. Itsekin olin mukana tuon tutkimusohjelman yh- 
dessä osaprojektissa, jossa pyrimme selvittämään tämän periaatteen toteutumista ja edistämisnäkymiä ammatillisen koulutuksen alueella.

$\mathrm{T}_{\mathrm{p}}$ utkimusryhmässämme totesimme 1990-luvun puolivälissä, että elinikäisen oppimisen periaatteella oli useimmiten viitattu koulutusjärjestelmään ja sen kehittämiseen elinikäisiä oppimismahdollisuuksia paremmin tarjoavaksi instituutioksi. Sen sijaan työelämän kehittäminen siten, että se edistäisi jatkuvan oppimisen mahdollisuuksia, näytti jääneen huomattavasti vähemmälle huomiolle. Loppuraportissamme (Tuomisto, Heikkilä, Juhela, Poikela \& Vuorikoski 1996) päädyimmekin painottamaan juuri työelämän kehittämistä jatkuvia oppimismahdollisuuksia tarjoavaksi.

Elinikäisen oppimisen konkretisointi tuottaa yhä vain huolta. Esimerkiksi Aikuiskasvatuksen numerossa 2/1999 opetusneuvos Jorma Ahola luonnostelee elinikäisen oppimisen edistämistä suomalaisessa elämänmenossa otsakkeella 'Mitä elinikäinen oppiminen on oikeasti käytännössä?' Siinä elinikäisen oppimisen ydintavoitteet tiivistetään kolmeen kohtaan, joissa korostetaan ennen muuta aikuisväestön mahdollisuuksia elinikäiseen oppimiseen sekä toisaalta koulutusjärjestelmän ulkopuolella tapahtuvan oppimisen nostamista koulutusjärjestelmässä tapahtuvan oppimisen rinnalle. Tavoitteet ovat sinänsä kannatettavia, mutta niiden konkretisointi on edelleen visainen tehtävä. Ratkottavien kysymysten ketjuun kun liittyvät paitsi koulutustavoitteet myös eri ikäiset ja erilaisen sosiaalisen taustan omaavat oppijat, eri koulutusinsituutioiden opettajat, hallintohenkilöstö, oppilaitokset, jne.

$\mathrm{O}_{\mathrm{s}}^{\mathrm{n}}$ syytä myös pitää mielessä, ettei elinikäisen oppimisen periaate ole neutraali asia, vaan sen käytäntöön saattamiseen liittyy hyvinkin erilaisia ja ristiriitaisia intressejä. Esimerkiksi ammatillisesta koulutuksesta ja kehitysmahdollisuuksista puhuttaessa voi elinikäisen oppimisen periaate merkitä hyvinkin erilaisia asioita riippuen siitä, katsotaanko asiaa työnantajan tai työntekijän näkökulmasta näkökulmasta (ks. Tuomisto \& Juhela 1996). Myös monet ammattikunnat, erityisesti professionaalistuneet tai profes-

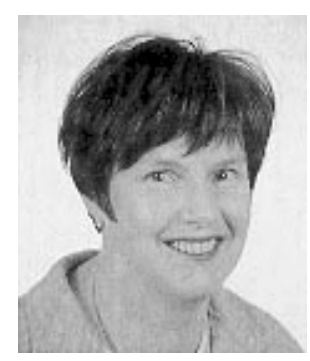

Marjo Vuorikoski

sionaalistumaan pyrkivät ammattiryhmät järjestöineen ovat aktiivisesti vaikuttamassa alansa koulutukseen ja sen sääntelyyn. Niiden tavoitteilla voi olla olennainen merkitys sille, missä muodossa elinikäisen oppimisen periaatetta ollaan valmiita edistämään käytännössä.

Elinikäistä oppimista koskeva tavoitekeskustelu jatkuu. Sen sijaan vähemmän näkee selvityksiä tai tutkimuksia siitä, miten elinikäisen oppimisen periaate on näkynyt jonkin ammattialan kehityksessä. Sosiaalityöntekijöiden koulutusta käsittelevässä tutkimuksessani on mukana tämä näkökulma. Sen yhtenä juonteena oli tarkastella, miten sosiaalityön alalla on kiinnitetty huomiota elinikäisten oppimismahdollisuuksien luomiseen.

\section{Intressiryhmät koulutusta m u ova a m a s a}

$\prod_{\mathrm{j}}$ utkimuksessani tarkastelen sosiaalityöntekijöiden koulutuksen kehittämistä ja alan professionaalistumista kytkeytyneinä suomalaisen hyvinvointivaltion muotoutumiseen 1940-luvulta lähtien. Kyseessä on yhden julkisissa hyvinvointipalveluissa toimivan naisvaltaisen ammattialan kehitystarina, jollaisia löytyisi muiltakin aloilta.

Analyysin pääkohde oli se, miten sosiaalityön koulutuksen eri intressiryhmät ovat pyrkineet ja pystyneet vaikuttamaan koulutukseen. Intressiryhmiksi erottelin sosiaalityöntekijät ammattijärjestöineen, sosiaalityön koulutusta järjestävien korkeakoulujen edustajat, valtion keskushallin- 
non edustajat sekä kunnalliset työnantajat. Eri intressiryhmien näkemyksiä koulutuksen kehittämiseen tutkin julkisessa keskustelussa esitettyjen kannanottojen perusteella. Lähdemateriaalina olivat sosiaalityön koulutusta suunnitelleiden komiteoiden, työryhmien ja toimikuntien mietinnöt sekä sosiaalialan aikakauslehtien koulutusta käsittelevät artikkelit.

Kiinnostukseni suuntautui sosiaalityön koulutusjärjestelmän kokonaisuuteen. Aineistosta analysoin eri intressiryhmien kannanottoja, jotka koskivat sosiaalityöntekijöiden koulutuksen tasoa, sisältöä ja määrällistä tarvetta. Lisäksi halusin tarkastella sitä, miten elinikäisen oppimisen periaatteeseen liittyvät ideat koulutuksen vertikaalisesta ja horisontaalisesta integroinnista ovat näkyneet sosiaalityön koulutusta kehitettäessä. Tästä syystä otin analyysin kohteeksi myös intressiryhmien näkemykset siitä, miten koulutuksen kehittämisessä on painotettu perus- ja lisäkoulutusta ja millaisia pyrkimyksiä on ollut niiden ja toisaalta koulutuksen ja työn integroimiseksi.

\section{Professiotavoite nousi 1970-luvulla}

$\mathrm{A}$ lun perin vapaaehtoistyön voimin hoidetun sosiaalityön polku akateemiseksi ammatiksi on ollut monivaiheinen. Ammattikunnan kasvu ja koulutuksen kehittäminen ovat kytköksissä suomalaisen hyvinvointivaltion muotoutumiseen. Sosiaalityöntekijöiden määrän lisääntyminen ja ammatillisen järjestäytymisen eteneminen merkitsivät myös, että ammattikunnan pyrkimykset alan professionaalistamiseksi alkoivat vahvistua. Professiopyrkimyksissähän ovat keskeisiä tieteellinen tieto ja koulutus sekä tietyn tehtäväalueen valtaaminen yhteiskunnallisessa työnjaossa (Abbott 1988; Helander 1993).

Tutkimustulosten perusteella sosiaalityön koulutuksen kehittämisestä ovat vastanneet pääasiassa valtion viranomaiset ja sosiaalityön koulutusta järjestävät tahot. Ne ovat olleet edustettuina koulutusta suunnitelleissa komiteoissa ja toimikunnissa ja myös dominoineet sosiaalityön koulutuksesta käytävää keskustelua. Sosiaalityönteki- jöiden ammattijärjestö on vasta 1970-luvulta lähtien onnistunut saamaan edustajiaan koulutusta suunnitteleviin elimiin.

Cosiaalityöntekijöiden pyrkimys ammatin proSessionaalistamiseksi nousi tietoiseksi toimintapolitiikaksi 1970-luvulla. Sosiaalityöntekijöiden ammattijärjestö ajoi voimallisesti koulutustason korotusta ja tiukempia kelpoisuusehtoja.

Professionaalistamispyrkimykset olivat niinikään 1980-luvun alussa myötätuulessa, sillä sosiaalityöntekijäkoulutus nostettiin ylemmän korkeakoulututkinnon tasoiseksi ja sosiaalityöntekijöille säädettiin sosiaalityön koulutusta edellyttävät kelpoisuusehdot. Jo 1980-luvun loppupuolella sosiaalityöntekijät joutuivat puolustusasemiin. Erityisesti työnantajataho kyseenalaisti tieteellisen koulutuksen ja tiukasti määriteltyjen kelpoisuusehtojen tarpeen. 1990-luvun alussa haasteita sosiaalityön yliopistolliselle koulutukselle toi ammattikorkeakoulujen perustaminen myös sosiaalialalle.

$\mathrm{M}$ utta intressitahoja ovat kiinnostaneet peuskoulutuksen ohella myös lisäkoulutukseen liittyvät kysymykset. Keskustelun teemat ovat aaltoilleet vuosikymmenten mittaan. Eri intressitahojen rintamalinjat ovat näkyvissä näissäkin keskusteluissa. Seuraavassa käyn yksityiskohtaisemmin läpi, miten elinikäisen oppimisen periaatteeseen liittyvät ideat ovat näkyneet sosiaalityön koulutuksessa ja kehittämistoiminnassa.

\section{Lisäkoulutuksen tarve esiin heti ammatillisen koulutuksen käynnistyttyä}

Vapaaehtoisuuden pohjalta tehtävä huolenpitotyö oli 1900-luvun alkuvuosikymmeninä alkanut muuttua entistä selvemmin palkattujen viranomaisten toiminnaksi. 1930-luvun lopulla sosiaalialan lisääntyvä lainsäädäntö johti tilanteeseen, jossa sosiaalihuollon tehtäviin katsottiin tarvittavan alan koulutuksen saanutta työvoimaa. (Ks. Satka 1994.)

Sosiaalityöntekijöiden koulutus organisoitiin 
hyvinvointivaltion rakentamisen lähtiessä käyntiin. Sosiaalityöntekijöiden pääasiallinen koulutusväylä, kaksivuotinen sosiaalihuoltajakoulutus käynnistyi vuonna 1942 Yhteiskunnallisessa Korkeakoulussa. Koulutuksen ensimmäisinä vuosikymmeninä, aina 1960-luvulle asti käytiin keskustelua lähinnä sosiaalityöntekijöiden koulutustarpeesta ja koulutuksen sisällöstä.

$\mathrm{K}^{\mathrm{s}}$ oulutuksen alkuvaiheessa eri intressitahot kiinnittivät huomiota siihen, ettei koulutus muodostuisi liian teoreettiseksi, sillä sosiaalityöntekijöiden katsottiin tarvitsevan käytännön osaamista. Koulutus sisälsikin useita harjoittelujaksoja. Teoreettisen ja käytännön opetuksen integrointia korostettiin kaikkien intressiryhmien puheenvuoroissa. Sosiaalityöntekijät, jotka varsin vähän osallistuivat koulutuksesta käytyyn julkiseen keskusteluun, ottivat kantaa nimenomaan käytännön opetuksen järjestelyyn.

Sosiaalityöntekijöiden täydennys- ja jatkokousen käynnistyessä. Alkuvaiheessa kuitenkin oli kyse ensisijassa vailla ammatillisia valmiuksia olevien työntekijöiden kouluttamisesta. Koska koulutettujen työntekijöiden puute paheni sosiaalihuollon lainsäädäntömuutosten myötä 1950luvun alussa, päädyttiin tilanteen korjaamiseksi järjestämään pikakoulutusta, mikä aikaansai kiistan eri intressiryhmien kesken.

Poikkeuskoulutuksen tarpeen kyseenalaistivat sosiaalihuoltajakoulutuksen saaneet, joiden mielestä koulutustarve olisi voitu täyttää lisäämällä koulutuksen sisäänottoa. Tämä kuvastaa myös ammattikoulutuksen saaneiden pyrkimystä suojata alaa lyhyemmän koulutuksen saaneilta. Heidän kannanotoillaan ei ollut paljonkaan painoarvoa, sillä koulutuksen ohjat olivat tiukasti sosiaalihallinnon virkamiesten ja koulutuksesta vastaavien käsissä. Lisäksi pätevyysehdotkin olivat koulutusedellytysten puolesta väljät.

1950-luvulla alkoivat nousta selvemmin esiin myös ammatillisen peruskoulutuksen saaneiden sosiaalityöntekijöiden täydennys- ja jatkokoulutustarpeet. Yhteiskunnallisessa Korkeakoulussa suunniteltiin sosiaalihuoltajien ammatillista jat- kokoulutusohjelmaa. Koska korkeakoulun suunnitelmat eivät toteutuneet ja sosiaalihuoltajien yhdistys järjesti osin näistä syistä 1950-luvulla useita sosiaalihuollon menetelmäseminaareja. Pontimena oli osittain se, että menetelmäkoulutusta ei onnistuttu sisällyttämään ammatilliseen peruskoulutukseen sosiaalihuoltajakoulutuksen johdon vastustuksen vuoksi.

Ammatillisen lisäkoulutuksen järjestämisvastuu alkoi kasautua järjestörintamalle. Suomen Huoltotyöntekijäin Liitto (vuodesta 1962 Sosiaalityöntekijäin Liitto) aloitti vuonna 1950 kirjeopistotoiminnan sekä järjesti vuosittain huoltopäiviä. Useat muutkin sosiaalialan yhdistykset ja järjestöt järjestivät vuosittaisia koulutus- ja neuvottelupäiviä. (Piirainen 1974, 378.) Täydennyskoulutustarjonnan yhä lisääntyessä 1960-luvulla pyrittiin koulutuksen järjestäjien välistä työnjakoa selkiyttämään. Vaikka päävastuuta täydennys- ja jatkokoulutuksen järjestämisestä tarjottiin useissa yhteyksissä alan peruskoulutuksesta vastaaville oppilaitoksille, jäi koulutustarjonta pääasiassa muiden tahojen vastuulle.

Hyvinvointivaltion toisessa rakennusvaiheessa 1960-luvulla sosiaalityöntekijöiden lisääntymistahti kiihtyi. Koulutuskeskustelussa eri intressiryhmien huomio alkoi entistä selvemmin kiinnittyä sosiaalityöntekijöiden koulutustason korottamiseen.

\section{Jatkuvan koulutuksen periaate nousi esiin 1970-luvulla}

$\int_{\text {luvun }}^{a}$ atkuvan koulutuksen periaate nostettiin 1970luvun alussa ensimmäistä kertaa esiin sosiaalityön koulutussuunnitelmien pohdinnassa. Tässä vaiheessa periaate kytkettiin ennen muuta ammatilliseen lisäkoulutukseen. Lisäkoulutuksen merkitys alettiin yleensäkin nähdä uudella tavalla. Koulutusta korostettiin tärkeänä kehityksen säätelijänä ja keskeisenä osana hallinnollista toimintaa. Koulutusajattelun uudistumisen taustana oli yhteiskunnallisten suunnittelujärjestelmien kehittyminen.

Sosiaalihallituksen täydennyskoulutusta pohtinut 
työryhmä (1971) toi ensimmäistä kertaa esiin jatkuvan koulutuksen periaatteen: "Nuorena saatu ammattikoulutus ei enää riitä, koska tiedon valtava kasvu ja uusiutuminen aiheuttavat muutoksia ammattitehtävissä kaikilla aloilla. Koulutusta tarvitaan jatkuvasti ainakin niin kauan kuin työelämään osallistuminen kestää. Ammatti on peruskoulutuksen lisäksi yhä enemmän opittava työpaikalla tai työn ohessa täydennyskoulutuksen muodossa." Ammattitaidon hankkimisen ja ylläpitämisen nähtiin siten olevan jatkuvaa oppimista edellyttävä prosessi.

Jatkuvan koulutuksen periaatteeseen liittyvä ajattelu heijastui myös sosiaalityön koulutuskomitean mietinnössä (KM 1972:A7), jota on pidetty sosiaalityön koulutuksen suunnittelun perusasiakirjana. Komitea korosti jatkokoulutuksen yhteen nivomista peruskoulutuksen kanssa. Lisäksi se esitti sosiaalityöntekijöiden täydennyskoulutuksen saattamista lakisääteiseksi.

Vaikka ajatus jatkuvan koulutuksen tarpeesta tuotiin sosiaalityön koulutuksesta käytyyn keskusteluun, ei se silti toiminut sosiaalityön koulutuksen kehittämisperiaatteena eikä noussut laajemmalti keskustelun kohteeksi. Siitä huolimatta tämän periaatteen ajatukset ovat käytännössä näkyneet koulutuksen kehittämisessä.

$\mathrm{K}$ oulutuskeskustelun keskiössä oli 1970-luvulla osiaalityön koulutustason korottaminen. Tässä vaiheessa myös sosiaalityön professionaalistamispyrkimykset nousivat entistä selvemmin esiin. Sosiaalityöntekijöiden ammattijärjestön tavoitteina oli korottaa koulutustasoa ja tiukentaa kelpoisuusehtoja. Koulutustason nostamiseen liittyvät kiistat lomittuivat korkeakoulujen tutkinnonuudistukseen ja keskiasteen koulutuksen uudistamissuunnitelmiin.

$V_{\text {him }}$ aikka koulutuksen intressiryhmien päähuomio suuntautui alan peruskoulutukseen, täydennyskoulutus laajeni entisestään ja sen merkitys ammattitaidon ajan tasalla pitämisessä ja kehittämisessä tunnustettiin entistä selkeämmin. Sekä sosiaalihallinnosta että järjestöistä tehtiin aloitteita täydennyskoulutuksen kehittämiseksi ja sen koordinaation lisäämiseksi. Näistä eri kou- luttajatahojen yhteistyöryhmien pyrkimyksistä huolimatta täydennyskoulutuksen tila näytti vuosikymmenen lopulla asiaa pohtineen sosiaalialan työryhmän mukaan varsin puutteelliselta. Pulmana olivat mm. koulutuksen riittämättömyys, koordinoimattomuus ja epätasainen jakautuminen eri tehtäväalueille. (Sosiaalialan koulutus 1977.)

$\mathrm{T}$ äydennyskoulutuksen lisäksi sosiaalityöntekijät olivat kiinnostuneita ammatillisesta jatkokoulutuksesta. Sosiaalityön eriytymiskehityksestä johtuen sosiaalityöntekijät toivat esiin erikoistumistarpeita. Tätä kysyntää vastaamaan kehittyi 1970-luvulta lähtien jatkokoulutusväyliä, joita ovat mm. useampia vuosia kestävät terapia-, ryhmätyö- ja työnohjauskoulutukset. Niitä järjestävät yliopistojen täydennyskoulutuskeskukset sekä sosiaali- ja mielenterveysalan järjestöt. Muodollista pätevyyttä jatkokoulutusväylät eivät juurikaan lisänneet. Vain kasvatusneuvolan sosiaalityöntekijän virassa edellytyksenä oli erikoistumiskoulutus.

Q amalla kun lisäkoulutuksen tarjonta laajeni, Nalettiin kiinnittää huomiota erilaisiin työssä oppimisen muotoihin ja myös työpaikkakoulutuksen tarve nostettiin esiin (mm. KM 1972:A7). Keskeisenä työssä oppimisen muotona sosiaalityön alueella alkoi yleistyä työnohjaus (ks. Karvinen 1991). Sosiaalityöntekijät ammattijärjestöineen pitivät tavoitteenaan työnohjausmahdollisuuksien luomista. Valtiovallan ja työnantajapuolen kiinnostus työnohjausta kohtaan lisääntyi vasta 1980-luvulla, jolloin sekä sosiaalihallinnon viranomaiset että kuntien keskusjärjestöt antoivat myös suosituksensa työnohjauksen järjestämisestä. Ylätavoitteeksi työnohjauksessa asetettiin palvelujen laadun parantaminen. Tämän lisäksi sillä katsottiin olevan sekä johtamiseen, työn kehittämiseen että työsuojeluun liittyviä tehtäviä (STM 1983:29, 9).

Vaikka työnohjaustarve periaatteessa tunnustettiin ja sosiaalityön työnohjaus laajeni, oli sen järjestämiselle käytännössä monia esteitä. Sosiaalityöntekijäin Liiton 1980-luvun puolivälissä tekemän jäsenkyselyn perusteella valtaosa sosiaalityöntekijöistä halusi työnohjausta, mutta vain noin puolella heistä oli mahdollisuus saada sitä. 
Esteinä olivat mm. vaikeudet löytää työnohjaajaa, hankaluudet irrottaa työaikaa työnohjaukseen sekä työnantajan riittämättömät tiedot työnohjauksesta. (Sosiaalityön työnohjaustyöryhmä 1987, 8.)

Vaikka sosiaalityön koulutuksen laajaa uudistusta suunniteltiin 1970-luvulla, oli sosiaalityöntekijöiden keskeinen koulutusväylä edelleen vuonna 1942 aloitettu sosiaalihuoltajakoulutus. Se oli säilynyt pääpiirteittäin entisenlaisena huolimatta yhteiskunnan ja sosiaalipolitiikan nopeasta muutoksesta. Sosiaalihuoltajakoulutuksen ulkoiset puitteet tosin olivat muuttuneet 1960luvulla, jolloin Yhteiskunnallinen Korkeakoulu muutti Tampereelle ja muuttui Tampereen yliopistoksi. Ammatillisen peruskoulutuksen muutoksen jähmeys näyttäisi ainakin osittain selittävän lisäkoulutuksen nopeaa laajenemista.

\section{Työn kehittämistoiminta käynnistyi 1980-luvulla}

Quomalaisen yhteiskunnan siirtyessä hyvinvoin1980-luvun alussa oli sosiaalityöntekijöiden professioprojekti myötuulessa. Intressiryhmien kesken oli viimein päästy ratkaisuun ja sosiaalityöntekijöiden koulutus uudistettiin vuosikymmenen alussa, jolloin se tutkinnonuudistuksessa nostettiin ylemmän korkeakoulututkinnon tasolle. Samoihin aikoihin myös sosiaalityöntekijöiden toinen tavoite toteutui, kun sosiaalityöntekijöille säädettiin alan koulutusta edellyttävät kelpoisuusehdot.

Kelpoisuusehtojen uudistaminen johti myös pätevöitymiskoulutuksen järjestämiseen, mikä saattoi sosiaalityöntekijäkunnan puolustusasemiin. Sosiaalityöntekijöiden ammattijärjestö pyrki kannanotoillaan vaikuttamaan siihen, ettei vuonna 1982 käynnistyneestä pätevöitymiskoulutuksesta muodostuisi "oikotietä" sosiaalityön virkoihin, vaan se pätevöittäisi jo alalla olevia eikä ohjaisi sosiaalityöhön muiden alojen reservejä. Sosiaalityöntekijöiden ammattijärjestö painotti toistumiseen yhtenäisen ammatillisen peruskoulutuksen tärkeyttä.
Lisäksi sosiaalityön professioprojektia varjosti 1980-luvulla koulutettujen sosiaalityöntekijöiden puute. Virkojen nopea lisääntyminen sekä toisaalta koulutusaikojen pidentyminen lisäsivät painetta poikkeuskoulutuksen järjestämiseen. Sosiaalityöntekijöiden ammattijärjestön vastustuksesta huolimatta käynnistettiin vuonna 1987 poikkeuskoulutusväylä lähialojen korkeakoulututkinnon suorittaneille.

Quunnitelmat sosiaalihuollon kokonaisuudisPuksesta vaikuttivat siihen, että sosiaalityöntekijöiden peruskoulutuksen uudistamisen ohella käynnistettiin 1980-luvun alkupuolella sosiaalihuollon tutkimus- ja kehittämistoimintaa sekä pyrittiin kehittämään alan täydennyskoulutusta. Pontta sille antoi myös työntekijäpula, jonka ratkaisemisessa koulutuksen lisääminen näytti rajalliselta keinolta.

Sosiaalihallituksella oli aktiivinen panos sekä sosiaalityön kehittämisprojektien käynnistäjänä että täydennyskoulutuksen kehittämisen ohjailijana. Sosiaalihallinnon roolin muuttuminen valvojasta toiminnan kehittäjäksi heijastaa osaltaan sitä modernisoitumiskehitystä, joka valtionhallinnossa oli käynnistynyt. Tämä merkitsi huomattavaa suunnanmuutosta. Ytimiin kuului ajatus sosiaalityöntekijästä aktiivisena työnsä tutkijana ja kehittäjänä, joka on osallisena tutkimustiedon tuottamisessa (ks. Arnkil 1991). Tämä idea poikkeaa oleellisesti aiemmasta tilanteesta, jossa sosiaalityöntekijät olivat pikemminkin 'kohteita' ja jossa tutkimustiedon tuottamistehtävän katsottiin kuuluvan akateemiselle yhteisölle.

Sosiaalihuollon tutkimus- ja kehittämisprojekteja käynnistettiin runsaasti sekä sosiaalihallituksessa että kunnissa ja ne tulivat osaksi sosiaalityöntekijöiden arkipäivää. Vuosikymmenen mittaan myös sosiaalityökeskustelussa alettiin painottaa näkemystä "sosiaalityöntekijästä oman työnsä kehittäjänä”. Tämä idea näkyi myös sosiaalityöntekijöiden täydennyskoulutuksen kehittämisessä, jota vauhditettiin 1980-luvulla lainsäädännöllä. Lisäksi periaatetta alettiin korostaa työnohjauksessa, jonka asema sosiaalitoimistoissa oli alkanut vakiintua (ks. Karvinen 1985). 
$\mathrm{S}_{\mathrm{n}}$ osiaalityön eri intressiosapuolilla oli kehittämässä erilaisia motiiveja ja tavoitteita. Rajavaara, joka itsekin toimi 1980-luvulla kehittämisprojektin vetäjänä, arvioi projekteja koskevassa analyysissaan monien ongelmien juontaneen tutkimustoiminnalle asetuista erilaisista odotuksista. Kun sosiaalihallinnon ja kuntapuolen edustajat korostivat henkilöstöpoliittisia tavoitteita sekä edullisesti tuotettavaa ja paremmin sovellettavissa olevaa tutkimustietoa, liittyi sosiaalityöntekijöiden ja alan tutkijoiden odotuksiin uratoiveita ja professionaalisia intressejä. (Rajavaara 1993, 27.)

Koulutuskeskustelussa usein esillä oleva aihe on ollut koulutuksen vastaavuus työelämän tarpeisiin. Erilaisten näkemysten ristiriita on tullut kärkevimmin esiin sosiaalityön koulutuksesta vastaavien ja kuntatyönantajien puheenvuoroissa. Yliopistoväen kannoissa on painotettu sitä, että sosiaalityöntekijät tarvitsevat laajan näkemyksen työn yhteiskunnallisista kytkennöistä ja tutkimuksellisia valmiuksia. Työnantajapuoli taas on kritisoinut koulutusta siitä, ettei se anna valmiuksia käytännön työhön.

Ratkaisua tähän teorian ja käytännön integroinnin pulmaan on 1980-luvulta lähtien etsitty kunnan sosiaalitoimen yhteyteen perustettavista 'koulutusklinikoista'. Konkreettisesti tämä hanke eteni, kun opetussosiaalikeskustoimikunta (KM 1990:48) 1990-luvun alussa esitti, että sosiaalityön opetusta antavien yliopistojen ja/tai lähipaikkakuntien sosiaalikeskuksista kehitetään yliopistollisia opetussosiaalikeskuksia. Niiden tehtävänä olisi perusopetuksen kehittämisen ohella osallistua sosiaalihuollon tutkimukseen ja kehittämiseen sekä alan ammatillisen jatko- ja täydennyskoulutuksen kehittäminen ja toteutukseen.

Vaikka opetussosiaalikeskusten perustamiseen päädyttiin, niiden kehittäminen ei kuitenkaan lähtenyt liikkeelle siinä mitassa kuin odotettiin. Uudistus käynnistyi juuri taloudellisen laman alla ja jäi heti alkuvaiheessaan supistuvan yliopistoja kuntatalouden katvealueelle. Yliopistojen laitokset pyrkivät silti muiden resurssien turvin viemään toimintaa eteenpäin. (Pohjola 1998, 56; STM 1997:4, 62-63.)
$\mathrm{L}$ amakauden jälkeen alettiin opetussosiaalikeskusten toimintaa jälleen elvyttää. Mm. sosiaalihuollon erityisosaamista pohtinut työryhmä (STM 1997:4) arvioi, että yliopistolliset opetussosiaalikeskukset voisivat tuottaa käytännön opetuksen ohjauksen ja järjestämisen ohella myös soveltavaa tutkimusta ja kehittämishankkeita sekä vastata täydennyskoulutuksesta. Myös korkeakoulujen edustajien näkemyksissä kannatettiin tällaisten keskusten aikaansaamista. Edellytyksenä näiden keskusten perustamiselle kuitenkin pidettiin toimivan yhteistyö-, rahoitus- ja virkarakenteen turvaamista. (Pohjola 1998, 60-62.)

1980-luvulla on selvästi näkyvissä siirtymää elinikäisen oppimisen ajatteluun. Alettiin painottaa työnkehittämistä. Se, samoin kuin laajentunut työnohjaus merkitsevät muutosta koulu- ja koulutuskeskeisestä ajattelusta kohti työssä ja muissa informaaleissa tilanteissa tapahtuvaa oppimista. Sekä opetussosiaalikeskusten että työn kehittämisprojektien voi katsoa palvelevan niinikään sosiaalityön professionaalistumista, sillä niiden myötä on paremmat mahdollisuudet suunnata sosiaalityön tutkimusta sosiaalityön kentällä tärkeinä pidettyihin ilmiöihin. Toisaalta ne ovat luomassa käytännön työssä toimiville sosiaalityöntekijöille luontevan tavan osallistua alansa tutkimukseen ja tiedontuotantoon.

\section{Erikoiskoulutusjärjestelmä alkoi hahmottua 1990-luvulla}

$\mathrm{H}$ yvinvointivaltion murrosvaiheessa 1990-luvun alussa nousi sosiaalityöntekijöiden koulutustaso uudelleen keskeiseksi teemaksi. Suunnitelmat sosiaalityöntekijöiden kelpoisuusehtojen väljentämisestä sekä ammattikorkeakoulujen perustaminen sosiaalialalle toivat haasteita sosiaalityön yliopistolliselle koulutukselle. Esiin nousi myös kysymys sosiaalialan koulutuskentän työnjaosta.

Ammatillisen peruskoulutuksen uudistamisen jälkeen päästiin kuitenkin vaiheeseen, jossa täydennyskoulutuksen ja tieteellisen jatkokoulutuksen oheen ryhdyttiin suunnittelemaan ammatillisia jatkokoulutusväyliä. Eri intressiryh- 
mät vaikuttivat varsin yksimielisiltä siitä, että ammatillisen erikoistumisen tulee tapahtua vasta peruskoulutuksen jälkeen.

Sosiaalityön erikoistumisohjelmien suunnittelu on ollut vireillä 1980-luvun lopulta lähtien ja eri yliopistoissa on 1990-luvulla käynnistetty erilaisia pitkäkestoisia koulutuksia. Erityisesti korkeakoulujen edustajat ovat olleet kiinnostuneita erikoistumisohjelmien aikaansaamisesta. Sehän tuo niille myös lisäresursseja, ja lisää virkoja (ks. Pohjola 1998, 73-74). Samalla se merkitsee paitsi sosiaalityön statuksen nousua myös sosiaalityön kouluttajien oman professiokehityksen etenemistä.

Erikoistumisväylien käynnistämistä ovat tukeneet myös korkeakoulujen lainsäädäntöön jätetyt lisensiaatintutkinnot, joista on kehitelty ammatillisesti painottuneita koulutusvaihtoehtoja työelämässä toimiville sosiaalityöntekijöille. Potentiaalisia jatkokoulutettavia löytyy paitsi sosiaalityöntekijöistä myös sosiaalialan ammattikorkeakoulujen opettajista. Erikoistumisväylien muotoutumiseen ja suosioon vaikuttaa tulevaisuudessa todennäköisesti se, johtaako erikoistumiskoulutuksen hankkiminen myös muutoksiin kelpoisuuksien määrittelyssä ja palkkauksessa. Tähän astihan lisäkoulutuksen hankkiminen ei ole taannut sosiaalityöntekijöille mahdollisuuksia työuralla etenemiseen tai palkkauksen paranemiseen.

Vuonna 2000 käynnistyvä erikoistumisjärjestelmä syntyy vaiheessa, jossa koko sosiaalialan koulutustilanne on melkoisessa murroksessa. Työ- ja koulutuskentän työnjaon pulmat sosiaalityön yliopistollisen koulutuksen ja sosiaalialan ammattikorkeakoulujen välillä ovat kiivaan tarkastelun alla. Parhaillaan on valmisteilla ammatinharjoittamislainsäädäntö, jonka voimalla sekä koulutuksen että ammatillisen kentän työnjaon pulmien toivotaan selviävän (ks. Malmström 1998; Pohjola 1998, 77-78). Koulutus- ja työmarkkinakentän selkiyttäminen lainsäädännöllä voi olla ammattikuntien professionaalisten pyrkimysten näkökulmasta ymmärrettävä tavoite, mutta työelämän kehittäminen vaatisi avoimuutta uusille ratkaisuille. Sitä taas liian tiukat ammattikuntien rajat voivat ehkäistä.

\section{Elinikäinen oppiminen ja intressit}

Q osiaalityön alalla ei koulutuskeskustelussa ole Suurikaan vannottu jatkuvan koulutuksen tai elinikäisen oppimisen periaatteen nimiin. Siitä huolimatta eri lisäkoulutuksen muodot ovat olleet kasvussa aina 1950-luvulta lähtien. Lisäksi sosiaalityöntekijöiden koulutuksessa on alusta pitäen korostettu teoreettisen ja käytännön opetuksen yhteennivomista. 1980-luvulta lähtien on sosiaalityön ja työorganisaatioiden kehittäminen vallannut alaa. Sen yhteydessäkään ei ole puhuttu elinikäisen oppimisen periaatteesta, vaan kehittämistoiminnan lähtökohtana olivat usein kehittävän työntutkimuksen mallin ideat. 1990luvun sosiaalityökeskusteluissa nostettiin esille reflektiivinen asiantuntijuus, joka pitää sisällään elinikäisen oppimisen perusajatuksen. Reflektiiviseen ammatillisuuteen pyrkiminen edellyttää jatkuvaa oppimista ja omien toimintakäytäntöjen arviointia ja kehittämistä (ks. Karvinen 1993; Satka 1997).

Tutkimuksen perusteella valtionhallinnon viranomaiset ja sosiaalityön koulutusta järjestävät tahot eivät ole olleet lisäkoulutuksen kehittämisessä yhtä keskeisessä asemassa kuin sosiaalityön peruskoulutuksessa. Etenkin koulutuksen ensi vuosikymmeninä sosiaalityöntekijöiden ja sosiaalialan järjestöillä oli merkittävä rooli täydennyskoulutuksen järjestäjinä. Lisäkoulutuksen järjestäminen jäi pitkälti järjestöille, kun alan peruskoulutusta järjestävät oppilaitokset eivät olleet halukkaita ottamaan sitä vastuulleen. Lisäkoulutuksen tehtävänä näyttää ainakin osittain olleen peruskoulutuksen puutteiden paikkailu.

Valtiovallan ohjailu lisäkoulutuksen organisoinnissa voimistui merkittävästi sosiaalihuoltolainsäädännön uudistuksen myötä 1980-luvun alussa, jolloin täydennyskoulutus tuli lakisääteiseksi. Samoin työn kehittämistoiminnan vauhdittamisessa keskushallinnolla oli aktiivinen rooli.

Kehittämisprojektit vetivät mukaansa myös sosiaalityön tutkijoita yliopistoista, minkä lisäksi monet sosiaalityön koulutusyksiköt hakeutuivat laajempaankin yhteistyöhön kuntien sosiaalitoi- 


\section{Vu or i k o s $k$ i}

men kanssa. Tätä kehitystä vauhditti myös opetussosiaalikeskusten perustaminen. Sosiaalityön peruskoulutusta järjestävien korkeakoulujen rooli lisäkoulutuksen organisoinnissa sai uuden suunnan, kun ne 1980-luvun lopulla kiinnostuivat erikoistumiskoulutuksen järjestämisestä.

Lisäkoulutukseen liittyviä kiistoja eri intressiryhmien kesken on tullut näkyvimmin esiin poikkeuskoulutusta käynnistettäessä koulutuksen ensi vuosikymmenillä ja jälleen 1980-luvulla, kun sosiaalityöntekijät itse eivät nähneet poikkeuskoulutusta oikeana ratkaisuna työntekijäpulaan. Lakisääteisillä kelpoisuusvaatimuksillakaan, jotka joutuivat uudelleen puntaroitaviksi jo 1990-luvun alussa, ei onnistuttu takaamaan ammatillisen kentän sulkemista, vaan ammattiin pääsy on mahdollista useita reittejä. Nyt tähän pyritään valmisteilla olevan ammatinharjoittamislainsäädännön avulla.

$\mathrm{P}$ rofessioiden ja professionaalistumaan pyrkivien ammattikuntien näkökulmasta elinikäisen oppimisen periaatteen suosio voi olla ainakin kahdenlainen riippuen siitä, mitä periaatteella tarkoitetaan. Mikäli tarkoituksena on kehittää ammatillisia lisäkoulutusmahdollisuuksia tarjoavaa täydennys- ja jatkokoulutusjärjestelmää, se on professiopyrkimysten näkökulmasta positiivinen seikka. Lisäkoulutusjärjestelmä on paitsi vahvistamassa työntekijöiden ammatillista osaamista, myös nostamassa ammattialan statusta.

Jos taas periaatteella viitataan avoimien koulutusväylien luomiseen ja koulutuksen ulkopuolella hankittujen ammatillisten valmiuksien nostamiseen koulutuksessa saatujen rinnalle, voivat professionaaliset ryhmät olla vähemmän innostuneita elinikäisestä oppimisesta. Professioille ja professionaalistumaan pyrkiville ammattikunnille yhtenäisen ammatillisen peruskoulutuksen merkitys on nimittäin myös siinä, että sen aikana ammattilaiset sosiaalistetaan ammatin kulttuuriin, sen arvoihin ja normeihin. Lisäksi profession tunnusmerkkeihin kuuluvat ammatin tieteellinen perusta ja tiukasti säädellyt kelpoisuusehdot. Avoin ja joustava koulutusjärjestelmä taas on vaikeasti yhteensovitettavissa niiden kanssa.

\section{Lähteet}

ABBOTT, A. (1988) The System of Professions. An Essay of Expert Labor. Chicago and London: The University of Chicago Press.

Aikuiskasvatus 2/1999. Mitä elinikäinen oppiminen on oikeasti käytännössä?

HELANDER, V. (1993) Professiot ja julkisvalta. Helsinki: Painatuskeskus.

KARVINEN, S. (1985) Työnohjaus ja työn kehittäminen sosiaalityössä. Sosiaalityön vuosikirja 1985. Sosiaalityöntekijäin Liitto. Helsinki.

KARVINEN, S. (1993) Reflektiivinen ammatillisuus sosiaalityössä. Teoksessa: R. Granfelt ym. (toim.) Monisärmäinen sosiaalityö. Sosiaaliturvan Keskusliitto. Helsinki.

KARVINEN, S. (1991) Työnohjaus sosiaalityön ammatillisuuden vaalijana. Teoksessa: Sosiaalityö ja työnohjaus. Sosiaalityön vuosikirja 1991. Sosiaalityöntekijäin Liitto ja VAPK-kustannus. Helsinki.

KM 1972:A7. Sosiaalityön koulutuskomitean mietintö

KM 1990:48. Opetussosiaalikeskustoimikunnan mietintö.

MALMSTRÖM, E. (1998) Sosiaalialan ammateille turvattu tulevaisuus. Pääkirjoitus. Sosiaalityöntekijä 2/1998.

PIIRAINEN, V. (1974) Vaivaishoidosta sosiaaliturvaan. Hämeenlinna: Karisto.

POHJOLA, A. (1998) Sosiaalityön yliopistollisen koulutuksen kehittäminen. Sosiaalityön koulutuksen selvityshenkilön raportti opetusministeriölle 27.2.1998. Opetusministeriö. Koulutus- ja tiedepolitiikan osasto/yliopistoyksikkö.

RAJAVAARA, M. (1993) Tuliko tutkivasta sosiaalityöstä mitään? Janus 1/1993.

SATKA, M. (1994) Sosiaalinen työ peräänkatsojamiehestä hoivayrittäjäksi. Teoksessa: J. Jaakkola, P. Pulma, M. Satka \& K. Urponen. Armelaisuus, yhteisöapu, sosiaaliturva. Suomalaisen sosiaaliturvan historia. Sosiaaliturvan Keskusliitto. Helsinki.

SATKA, M. (1997) Sosiaalityön tulevaisuutta rakentamassa. Artikkeleita opetuksen uudistamisesta. Jyväskylän yliopiston yhteiskuntapolitiikan työpapereita no. 101. Jyväskylä.

Sosiaalialan koulutus (1977). Työseminaari 30.5.-3.6. 1977 Tampereen yliopiston täydennyskoulutuskeskuksessa. Sosiaalihallitus ja Tampereen yliopiston täydennyskoulutuskeskus.

Sosiaalihallituksen asettaman sosiaalihuollon koulutuksen työryhmän muistio (1971). Sosiaalihuollon henkilökunnan täydennyskoulutus

Sosiaalityön työnohjaustyöryhmä (1987). Sosiaalityöntekijäin Liitto.

STM 1983:29. Työnohjausryhmän muistio. Sosiaali- ja terveysministeriön työryhmämuistioita. Helsinki.

STM 1997:4. Sosiaalihuollon erityisosaamisen turvaaminen. Sosiaalihuollon erityisosaamista selvittäneen työryhmän muistio. Sosiaali- ja terveysministeriön työryhmämuistioita. Helsinki.

TUOMISTO, J., Heikkilä, K., Juhela, A., Poikela, E. \& Vuorikoski, M. (1996) Yhteiskunnan rakenteet ja elinikäinen oppiminen. Tampereen yliopisto. 


\section{A R T I K K E L I T}

Kasvatustieteiden laitos, julkaisusarja A/59. Tampere.

TUOMISTO, J. \& Juhela, A. (1996) Elinikäistä oppimista tukeva työ- ja koulutusjärjestelmä - ongelmat, haasteet ja kehittämismahdollisuudet. Teoksessa: J. Tuomisto, K. Heikkilä, A. Juhela, E. Poikela \& M. Vuorikoski. Yhteiskunnan rakenteet ja elinikäinen oppiminen. Tampereen yliopisto. Kasvatustieteiden laitos, julkaisusarja A/59. Tampere.

VUORIKOSKI, M. (1999) Sosiaalityön professionaalistuminen ja koulutus. Acta Universitatis Tamperensis 687. Tampereen yliopisto. Vammala: Vammalan Kirjapaino.
Artikkeli perustuu Tampereen yliopiston kasvatustieteellisessä tiedekunnassa 19.6.1999 tarkastettuun väitöskirjaan Sosiaalityön professionaalistuminen ja koulutus (Vuorikoski 1999).

Artikkeli saapui toimitukseen 2.11.1999. Se hyväksyttiin julkaistavaksi 31.1.2000. 